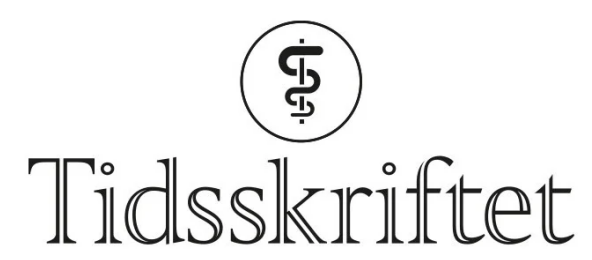

DEN NORSKE LEGEFORENING

\title{
Mer norsk farmakologi for sykepleiere
}

ANMELDELSER

GUTTORM RAKNES

Steigen legesenter

Leinesfjord

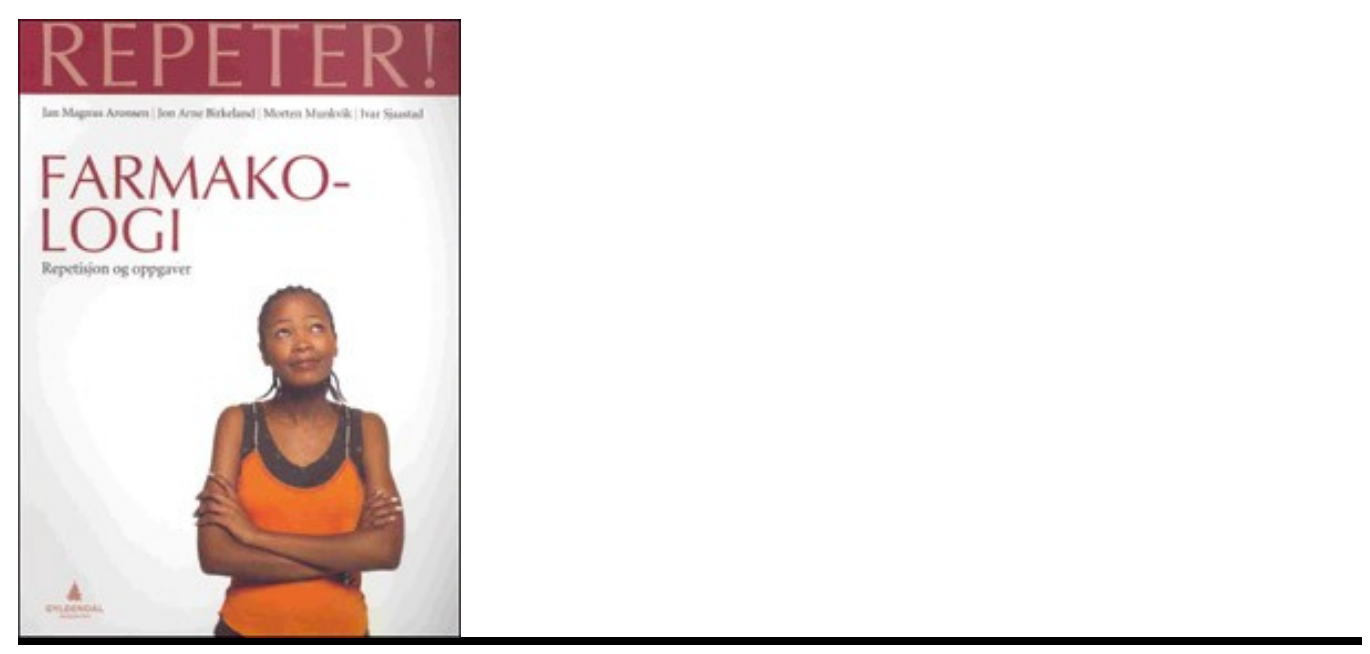

Aronsen, Jan Magnus

Birkeland, Jon Arne

Munkvik, Morten

Repeter! Farmakologi

Repetisjon og oppgaver. 207, ill. Oslo: Gyldendal Akademisk, 2011. Pris NOK 269

ISBN 978-82-05-40130-3

De senere årene har det kommet flere vellykkede norske lærebøker i farmakologi for sykepleiestudenter. Simonsen og medarbeideres verk selger godt både i Norge og flere andre land (1), mens Nordeng \& Spigsets lærebok er blitt godt mottatt av anmeldere (2 $)$. Mange medisinstudenter har også omfavnet disse verkene som lettere alternativer til tunge, detaljerte standardverker innen klinisk farmakologi. 
Gyldendal har i samarbeid med Bjørknes Høyskole kommet med nok en norskspråklig farmakologibok rettet mot sykepleieutdanningen. Boken er en del av serien «Repetér!», ment for eksamensforberedelser. Med på kjøpet følger en kode som åpner for tilleggsstoff og oppgaver på Internett. I skrivende stund er denne tjenesten tilsynelatende ikke kommet på beina, i alle fall var ikke jeg i stand til å finne noe ekstramateriell på den oppgitte nettsiden.

Første firedel vies generell farmakologi, hvor bl.a. sentrale begreper og prinsipper innen farmakokinetikk og -dynamikk presenteres på en klar og lettlest måte. Del 2 tar for seg legemidler som virker ved generelle sykdomsmekanismer og symptomer. Siste halvdel omhandler behandling av organspesifikke sykdommer.

Boken dekker alle sentrale deler av farmakologien, den er oppdatert og det er vanskelig å finne faktafeil. Kildehenvisninger eller forslag til videre lesing er det imidlertid ikke satt av plass til, og for medisinere er stoffet såpass overfladisk presentert at boken ikke kan anbefales som annet enn et supplement.

Teksten bærer preg av å være mer en ordinær lærebok enn det tittelen tilsier. I en repetisjonsbok kunne man f.eks. ønske seg flere oversiktstabeller og figurer. Den største svakheten er likevel at det ikke er noe stikkordregister, noe som gjør det upraktisk å slå opp i boken. Som eksamensforberedende bok er det oppgavene som fungerer best, her finner man bl.a. sykehistorier med tilhørende problemstillinger.

Sykepleiere omgås legemidler til daglig og har en nøkkelrolle i kartlegging av ønskede og uønskede effekter av legemidler hos ulike pasientgrupper. Kunnskapsnivået innen farmakologi for sykepleiere som denne boken legger opp til er betryggende.

\section{LITTERATUR}

1. Simonsen T, Aarbakke J, Lysaa R. Illustrert farmakologi. 3. utg. Bergen: Fagbokforlaget, 2010.

2. Nordeng H, Spigset O, red. Legemidler og bruken av dem. Oslo: Gyldendal Akademisk, 2007.

Publisert: 23. august 2011. Tidsskr Nor Legeforen. DOI: 10.4045/tidsskr.11.0388

C Tidsskrift for Den norske legeforening 2023. Lastet ned fra tidsskriftet.no 26. april 2023. 